
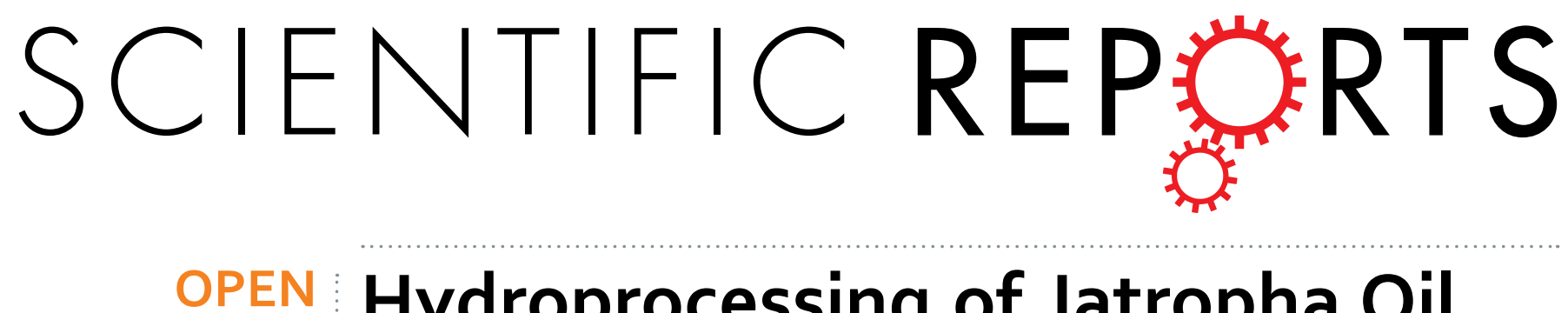

\title{
Hydroprocessing of Jatropha Oil for Production of Green Diesel over Non-sulfided Ni-PTA/Al $\mathrm{O}_{3}$ Catalyst
}

Received: 28 July 2014 Accepted: 21 May 2015 Published: 10 July 2015

\author{
Jing Liu ${ }^{1}$, Jiandu Lei ${ }^{1}$, Jing He${ }^{1}$, Lihong Deng ${ }^{1}$, Luying Wang ${ }^{1}$, Kai Fan² \& Long Rong ${ }^{2}$
}

The non-sulfided Ni-PTA/Al $\mathrm{O}_{3}$ catalyst was developed to produce green diesel from the hydroprocessing of Jatropha oil. The Ni-PTA/Al $\mathrm{O}_{3}$ catalyst was prepared by one-pot synthesis of $\mathrm{Ni} / \mathrm{Al}_{2} \mathrm{O}_{3}$ with the co-precipitation method and then impregnanting $\mathrm{Ni} / \mathrm{Al}_{2} \mathrm{O}_{3}$ with PTA solution. The catalysts were characterized with BET, SEM-EDX, TEM, XRD, XPS, TGA and $\mathrm{NH}_{3}-\mathrm{TPD}$. The $\mathrm{Ni}$ and $\mathrm{W}$ species of the Ni-PTA/Al $\mathrm{O}_{3}$ catalyst were much more homogeneously distributed on the surface than that of commercial $\mathrm{Al}_{2} \mathrm{O}_{3}$. Catalytic performance in the hydroprocessing of Jatropha oil was evaluated by GC. The maximum conversion of Jatropha oil ( $98.5 \mathrm{wt} \%)$ and selectivity of the $\mathrm{C}_{15}-\mathrm{C}_{18}$ alkanes fraction ( $84.5 \mathrm{wt} \%$ ) occurred at $360^{\circ} \mathrm{C}, 3.0 \mathrm{MPa}, 0.8 \mathrm{~h}^{-1}$. The non-sulfided Ni-PTA/Al $\mathrm{O}_{3}$ catalyst is more environmentally friendly than the conventional sulfided hydroprocessing catalyst, and it exhibited the highest catalytic activity than the Ni-PTA catalyst supported with commercial $\mathrm{Al}_{2} \mathrm{O}_{3}$ grain and $\mathrm{Al}_{2} \mathrm{O}_{3}$ powder.

Renewable and clean fuel sources are currently in high demand, due to environmental challenges such as climate change, diminishing fossil fuel reserves and deteriorating quality of crude oil ${ }^{1}$. In recent years, hydroprocessing of vegetable oil for hydrocarbons (commonly called green diesel) has become more popular. Jatropha oil has several advantages. It is an ideal source of triglycerides does not compete with arable land for food, and may yield more biofuel per hectare than canola, sunflower, and soyabeans ${ }^{2}$. Its hydroprocessing product contains mainly normal C17 and C18 paraffins with a high cetane number.

In the past, conventional hydrogenation catalysts such as sulfided NiMo-alumina or CoMo-alumina have been commonly used ${ }^{3}$, and noble metal catalysts such as Pt or Pd based-catalysts have been also reported ${ }^{4}$. Alumina is popular due to its moderate acidity and reduced cracking activity, leading to a high yield of green diesel. Normal alumina has a relatively large specific surface area (about $200 \mathrm{~m}^{2} / \mathrm{g}$ ), but still cannot meet the demand of the chemical and petrochemical industries. A catalyst with a small pore diameter or low specific surface area would decrease its catalytic activity by restricting the access of reactants to the catalytic sites or decreasing the numbers of activity sites per unit area. Appropriate amount of macropores can promote the desorption of the products, following by the inhibition of some side reactions ${ }^{6}$. Yin et al. ${ }^{7}$ studied the effect of alumina support on the catalytic performance of Pt-Sn/ $\mathrm{Al}_{2} \mathrm{O}_{3}$ catalysts in one-step synthesis of N-phenylbenzylamine from aniline and benzyl alcohol. They found that the large pore volumes and pore size distributions of alumina supports aided in diffusion and adsorption of reactants on the catalyst surface and increased the catalytic activity. Alumina supports were also found to help remove products from the catalyst surface and enhanced catalytic stability.

The use of alumina-supported transition metal as a catalyst has been found ${ }^{8-10}$ to produce $\mathrm{n}$-alkanes from triglycerides of palm oil, soybean oil and other vegetable oils. However, few studies have explored the effects of of alumina structure on hydroprocessing activity. Furthermore, transition metal catalysts are usually sulfided to retain their active form ${ }^{11}$. This may cause sulfur dioxide emissions, corrosion and sulfur residues in the products under long-term reaction, since vegetable oils are free of sulfur

${ }^{1}$ MOE Key Laboratory of Wooden Material Science and Application, Beijing Forestry University, Beijing 100083, P. R. China. ${ }^{2}$ Key Laboratory for Biomechanics and Mechanobiology of Ministry of Education, School of Biological Science and Medical Engineering, Beihang University, Beijing 100191, P. R. China. Correspondence and requests for materials should be addressed to J.L. (email: leijiandu@tsinghua.org.cn) or L.R. (email: ronglong@buaa.edu.cn) 

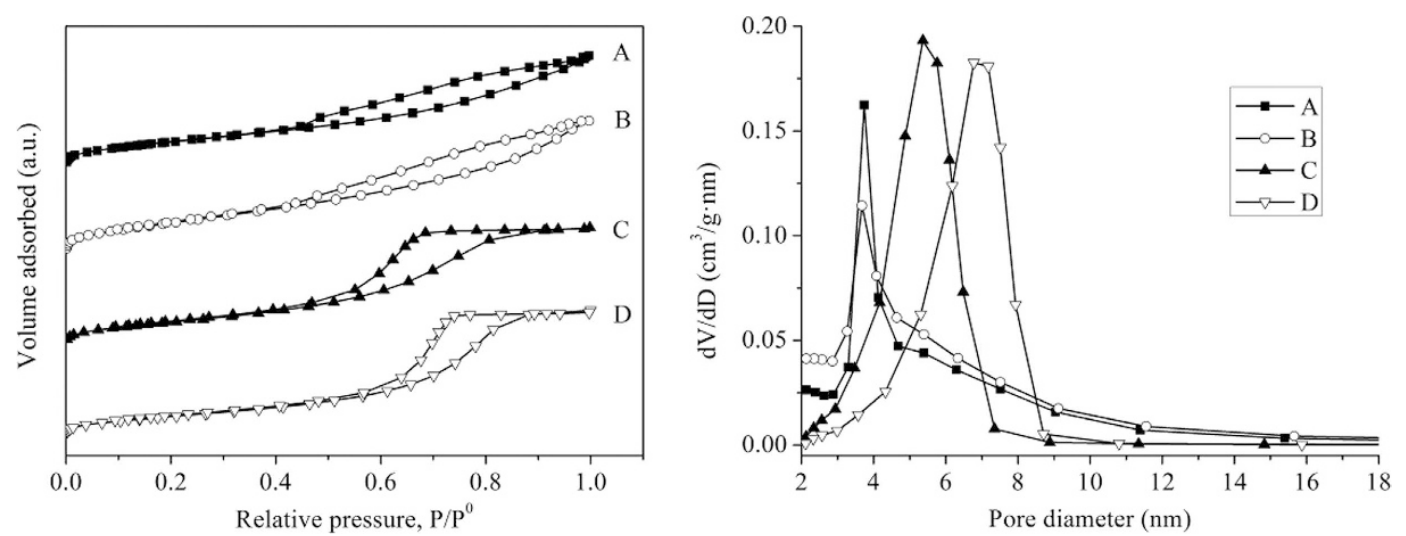

Figure 1. Nitrogen adsorption-desorption isotherms and pore size distribution of (A) commercial $\mathrm{Al}_{2} \mathrm{O}_{3}$ grain, (B) commercial $\mathrm{Al}_{2} \mathrm{O}_{3}$ powder, $(\mathbf{C})$ synthetic $\mathrm{Al}_{2} \mathrm{O}_{3}$ support and (D) synthetic Ni-PTA/ $\mathrm{Al}_{2} \mathrm{O}_{3}$ catalyst.

\begin{tabular}{|l|c|c|c|}
\hline Samples & $\begin{array}{c}\text { Specific surface } \\
\text { areas, } \mathbf{~ m}^{2} \mathbf{g}\end{array}$ & $\begin{array}{c}\text { Total pore } \\
\text { volume, } \mathbf{c m}^{3} \mathbf{g}\end{array}$ & $\begin{array}{c}\text { Average pore } \\
\text { diameter, } \mathbf{~ n m}\end{array}$ \\
\hline Commercial $\mathrm{Al}_{2} \mathrm{O}_{3}$ grain & 207 & 0.38 & 5.18 \\
\hline Commercial $\mathrm{Al}_{2} \mathrm{O}_{3}$ powder & 257 & 0.42 & 4.84 \\
\hline Synthetic $\mathrm{Al}_{2} \mathrm{O}_{3}$ support & 296 & 0.43 & 6.32 \\
\hline Synthetic $\mathrm{Ni}_{-} \mathrm{PTA} / \mathrm{Al}_{2} \mathrm{O}_{3}$ catalyst & 232 & 0.44 & 7.49 \\
\hline
\end{tabular}

Table 1. Textural properties of different $\mathrm{Al}_{2} \mathrm{O}_{3}$ samples.

compounds. Thus the quality of green diesel might be affected if the product oil contained sulfur residuals. Although noble metal catalysts showed high catalytic activity without sulfidizing process, they were not suitable for the large-scale process due to their high cost. Our previous work successfully prepared non-sulfided rare metal ${ }^{12}$ and heteropolyacid catalysts ${ }^{13,14}$ prepared by wet co-impregnation method to produce the straight chain alkanes $\mathrm{C} 15$ to $\mathrm{C} 18$. In the current study, we prepared alumina-supported nickel and phosphotungstic acid $\left(\mathrm{Ni}-\mathrm{PTA} / \mathrm{Al}_{2} \mathrm{O}_{3}\right)$ catalysts with a large pore volume and pore size to produce green diesel without sulfidation. Large pore sizes favor the diffusion of large-size fatty acid molecules ${ }^{15}$. The co-precipitation method was used to prepare $\mathrm{Ni} / \mathrm{Al}_{2} \mathrm{O}_{3}$ in order to obtain homogenous and more metal activity sites. In addition, we compared the hydroprocessing activity of catalysts with synthetic alumina support to that of commercial alumina supports.

\section{Results}

Catalyst characterization. The nitrogen adsorption-desorption isotherms of the $\mathrm{Al}_{2} \mathrm{O}_{3}$ samples were showed in Fig. 1. The adsorption of two commercial alumina supports $\left(\mathrm{A}: \mathrm{Al}_{2} \mathrm{O}_{3}\right.$ grain and $\mathrm{B}: \mathrm{Al}_{2} \mathrm{O}_{3}$ powder) increased gradually as relative pressure increased, and then increased rapidly at a high relative pressure $\left(\mathrm{P} / \mathrm{P}^{0}>0.4\right)$. This displayed Langmuir type IV isotherms with a H4-type hysteresis loop in the IUPAC classification ${ }^{16}$. This type is often associated with a typical mesoporous material with size-homogeneous $1 \mathrm{D}$ slit channels ${ }^{17}$. The synthetic alumina supports $(\mathrm{C})$ and $\mathrm{Ni}-\mathrm{PTA} / \mathrm{Al}_{2} \mathrm{O}_{3}$ catalyst (D) exhibited H2-type hysteresis loops characteristic of solids with ink bottle pores. The pore network structure may be interconnected or independent ${ }^{18}$. According to the nitrogen adsorption-desorption isotherms, it is evident that the total adsorption of the synthetic samples was larger than that of the commercial samples.

Pore size distribution can be calculated from the desorption branches of the isotherms according to the BJH (Barrett-Joyner-Halenda) method. Curves were displayed in Fig. 1. Each sample presented a characteristic of mesoporous structure. A comparison of the textural properties of the $\mathrm{Al}_{2} \mathrm{O}_{3}$ samples was shown in Table 1. Commercial $\mathrm{Al}_{2} \mathrm{O}_{3}$ grain (A) and $\mathrm{Al}_{2} \mathrm{O}_{3}$ powder (B) both have a very narrow pore size distribution, with an average pore diameter of $5.18 \mathrm{~nm}$ and $4.84 \mathrm{~nm}$, respectively. In synthetic alumina supports (C) and $\mathrm{Ni}-\mathrm{PTA} / \mathrm{Al}_{2} \mathrm{O}_{3}$ catalyst (D), the curves presented a unimodal pore structure with a little wider distribution in the mesoporous range (2-7 $\mathrm{nm}$ and 2-9 $\mathrm{nm}$, respectively). Table 1 shows that synthetic $\mathrm{Al}_{2} \mathrm{O}_{3}$ support had a considerably high surface area $\left(296 \mathrm{~m}^{2} / \mathrm{g}\right)$, while the surface area of the prepared catalyst was lower than that of the $\mathrm{Al}_{2} \mathrm{O}_{3}$ support due to the deposit of the metal on the support surface ${ }^{19}$.

The synthetic $\mathrm{Al}_{2} \mathrm{O}_{3}$ support was characterized by SEM, as shown in Fig. 2. Scanning electron micrographs showed the morphologies and pore structure. It is evident that the synthetic $\mathrm{Al}_{2} \mathrm{O}_{3}$ support 

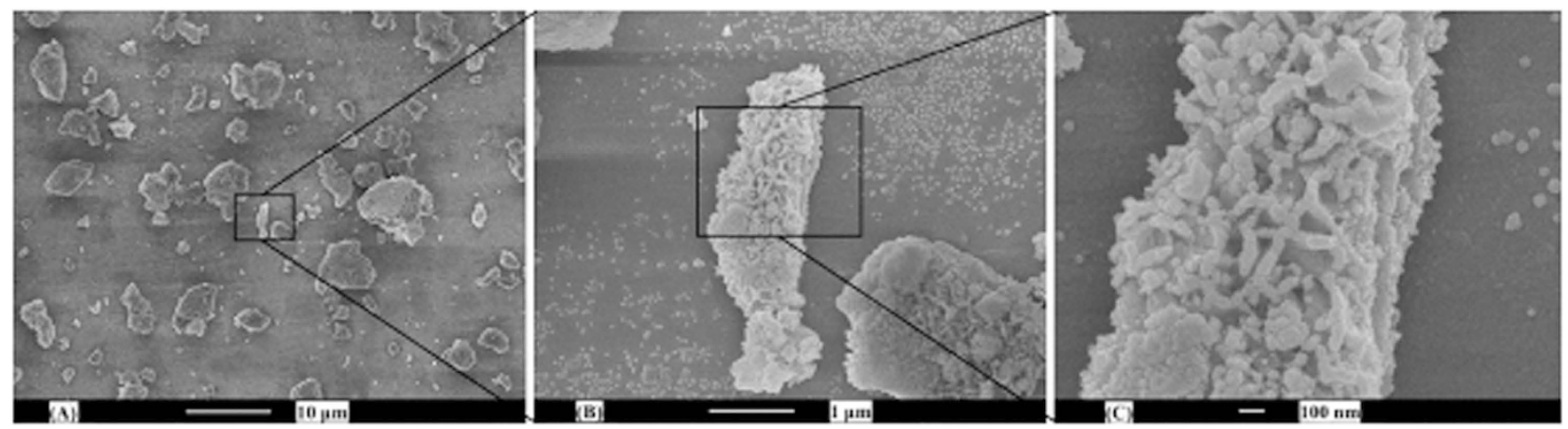

Figure 2. Scanning electron microscope images of synthetic $\mathbf{A l}_{2} \mathbf{O}_{3}$ support $(\mathbf{A}) \times 2000,(\mathbf{B}) \times 20000$ and (C) $\times 60000$.

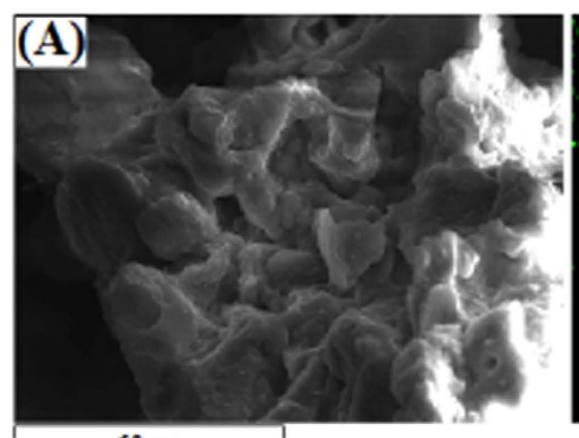

$60 \mu \mathrm{m}$

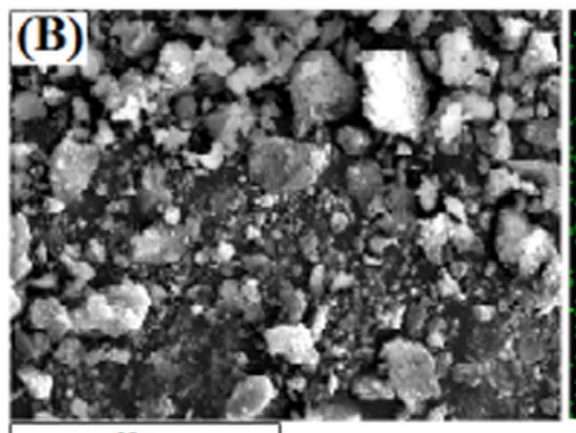

$60 \mu \mathrm{m}$

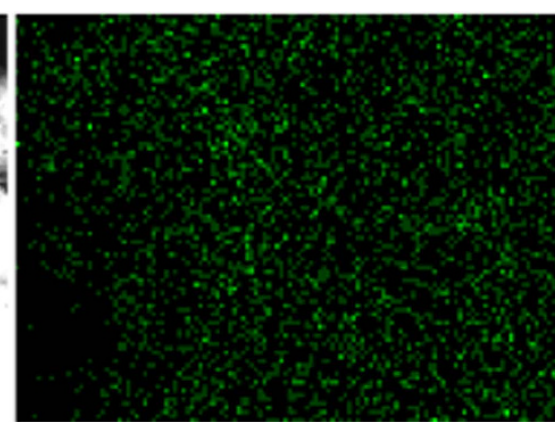

$\mathrm{Ni}$

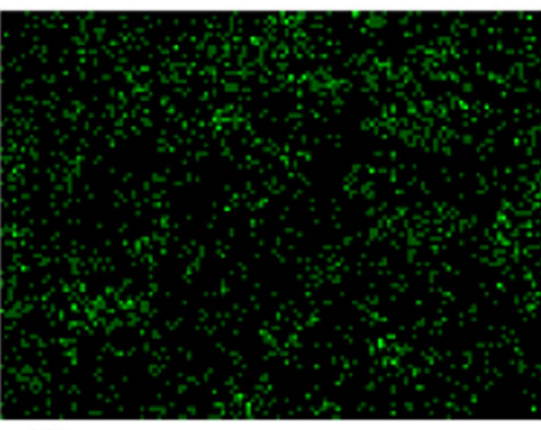

$\mathrm{Ni}$

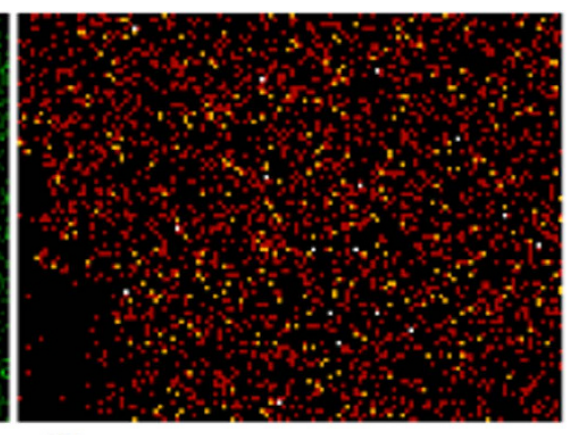

W

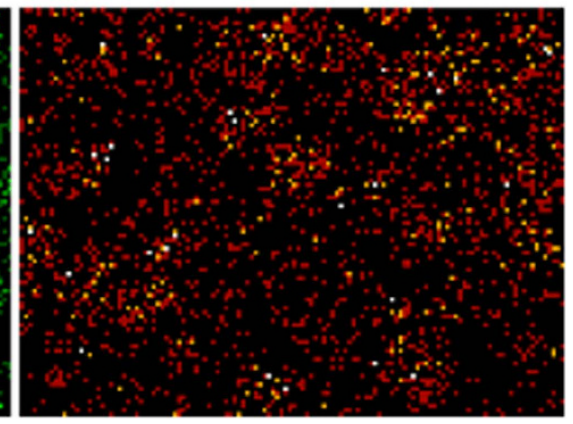

W

Figure 3. SEM and EDX elemental mappings for the synthetic Ni-PTA/ $/ \mathrm{Al}_{2} \mathrm{O}_{3}$ catalyst (A) and $\mathrm{Ni}-\mathrm{PTA} / \mathrm{Al}_{2} \mathrm{O}_{3}$ powder (B).

presented a mesoporous structure with small pores. The pore structure was identical with the results obtained from BET.

Figure 3 showed the $\mathrm{Ni}$ and $\mathrm{W}$ species distributed on the alumina surface as shown in SEM-EDX images of synthetic Ni-PTA $/ \mathrm{Al}_{2} \mathrm{O}_{3}$ catalyst and $\mathrm{Ni}-\mathrm{PTA} / \mathrm{Al}_{2} \mathrm{O}_{3}$ powder. The $\mathrm{Ni}$ and $\mathrm{W}$ species on the synthetic Ni-PTA/ $\mathrm{Al}_{2} \mathrm{O}_{3}$ catalyst (Fig. $3 \mathrm{~A}$ ) were much more homogeneously distributed on the surface. However, $\mathrm{Ni}$ and $\mathrm{W}$ on the $\mathrm{Ni}-\mathrm{PTA} / \mathrm{Al}_{2} \mathrm{O}_{3}$ powder (Fig. $3 \mathrm{~B}$ ) displayed large spots, suggesting that the $\mathrm{Ni}$ and $\mathrm{W}$ were not well distributed compared with synthetic $\mathrm{Ni}-\mathrm{PTA} / \mathrm{Al}_{2} \mathrm{O}_{3}$ catalyst. Furthermore, EDX measurements were made to determine the chemical composition of the catalyst, and quantitative analysis of different elements showed that the synthetic Ni-PTA/ $\mathrm{Al}_{2} \mathrm{O}_{3}$ catalyst (A) contained $5.74 \mathrm{wt} \% \mathrm{Ni}$, 11.63 wt $\% \mathrm{~W}, 0.80$ wt $\% \mathrm{P}$ and 35.09 wt $\% \mathrm{Al}$, while Ni-PTA $/ \mathrm{Al}_{2} \mathrm{O}_{3}$ powder (B) contained $2.43 \mathrm{wt} \% \mathrm{Ni}$, 7.93 wt $\% \mathrm{~W}, 0.23 \mathrm{wt} \% \mathrm{P}$ and $34.05 \mathrm{wt} \% \mathrm{Al}$. This indicated that the metal content of synthetic Ni-PTA/ $\mathrm{Al}_{2} \mathrm{O}_{3}$ catalyst was higher than that of the $\mathrm{Ni}-\mathrm{PTA} / \mathrm{Al}_{2} \mathrm{O}_{3}$ powder.

The transmission electron microscopy technique was used to further measure the nickel particle size and dispersion of metal. TEM images of synthetic $\mathrm{Ni} / \mathrm{Al}_{2} \mathrm{O}_{3}$ and $\mathrm{Ni}-\mathrm{PTA} / \mathrm{Al}_{2} \mathrm{O}_{3}$ catalysts were shown in Fig. 4. The black nickel particles were clearly evident in the images, and the dimension of nickel particle estimated from the TEM image was about $10 \mathrm{~nm}$. Figure $4 \mathrm{~A}, \mathrm{~B}$ showed the composition of random, 

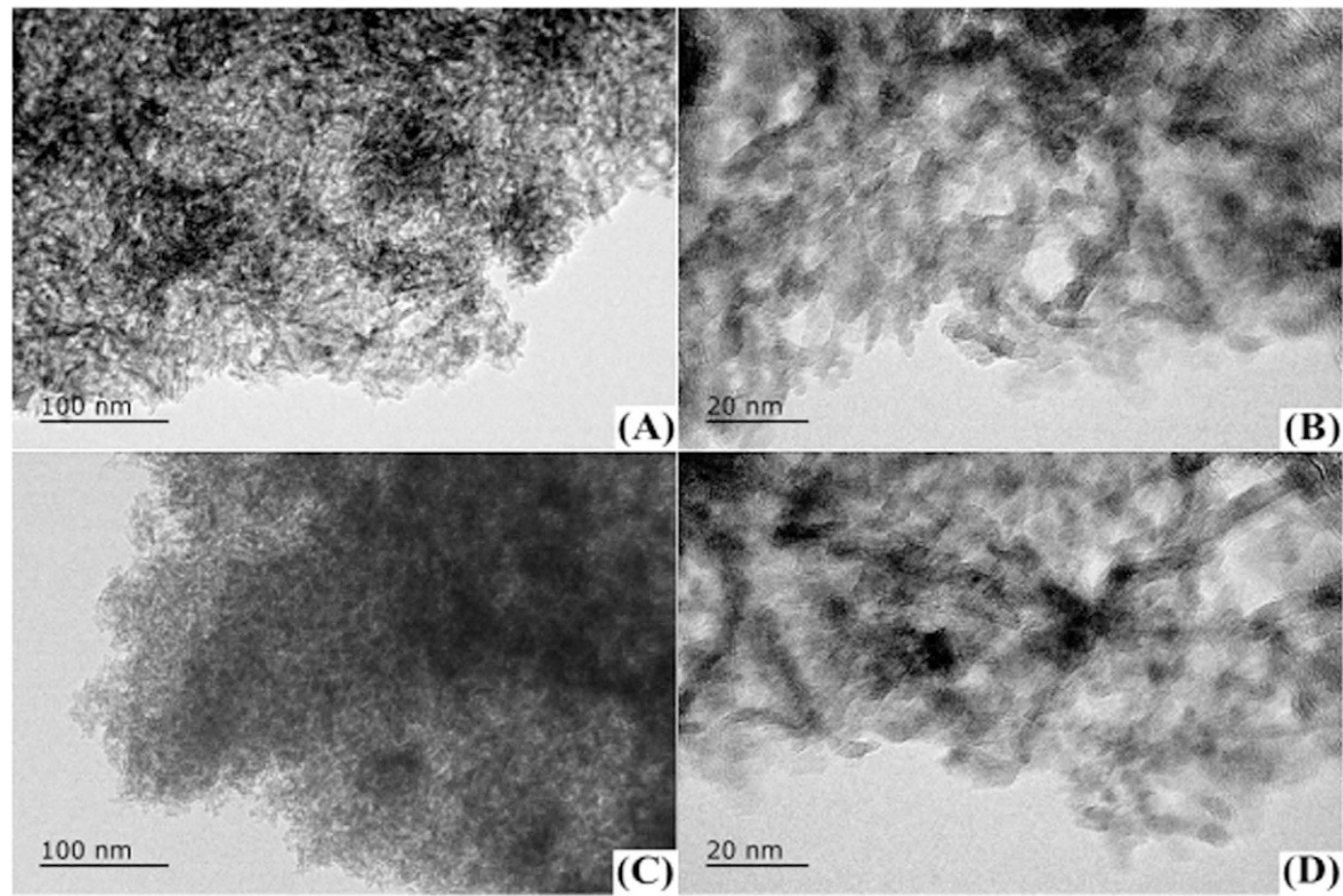

Figure 4. Transmission electron microscopy images of the synthetic $\mathrm{Ni} / \mathrm{Al}_{2} \mathrm{O}_{3}$ catalyst $(\mathbf{A}) \times 200 \mathrm{k},(\mathbf{B}) \times 800 \mathrm{k}$ and synthetic Ni-PTA $/ \mathrm{Al}_{2} \mathrm{O}_{3}$ catalyst $($ C $) \times 200 \mathrm{k},($ D $) \times 800 \mathrm{k}$.

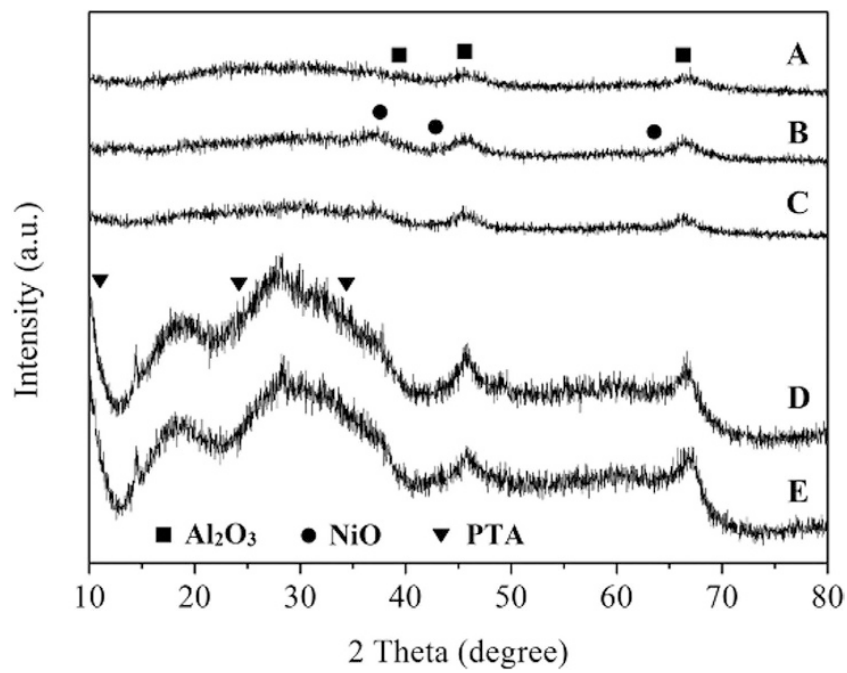

Figure 5. XRD patterns of (A) synthetic $\mathrm{Al}_{2} \mathrm{O}_{3}$ support, (B) synthetic $\mathrm{Ni} / \mathrm{Al}_{2} \mathrm{O}_{3}$ catalyst and (C) synthetic $\mathrm{Ni}-\mathrm{PTA} / \mathrm{Al}_{2} \mathrm{O}_{3}$ catalyst, (D) Ni-PTA/ $\mathrm{Al}_{2} \mathrm{O}_{3}$ grain, (E) $\mathrm{Ni}-\mathrm{PTA} / \mathrm{Al}_{2} \mathrm{O}_{3}$ powder.

stack-like particles. The distribution of Ni particles was relatively uniform in Fig. 4C,D. This suggested that adding PTA may promote the dispersion of Ni particles. Moreover, the pore diameter from Fig. 4B,D was about $2-10 \mathrm{~nm}$, which was confirmed by BET results. It can be deduced that the mesopores were formed due to a slew of particles connected mutually during co-precipitation and the intervals among particles formed during calcination.

The XRD pattern of synthetic $\mathrm{Al}_{2} \mathrm{O}_{3}$ support, $\mathrm{Ni} / \mathrm{Al}_{2} \mathrm{O}_{3}$ catalyst and $\mathrm{Ni}-\mathrm{PTA} / \mathrm{Al}_{2} \mathrm{O}_{3}$ catalyst were shown in Fig. 5. All samples exhibited characteristic peaks at $2 \theta=38^{\circ}, 46^{\circ}$ and $66^{\circ}$ correspond to (311), (400) and (440) plane of $\gamma-\mathrm{Al}_{2} \mathrm{O}_{3}$, respectively ${ }^{5}$. The peaks observed at $2 \theta=37^{\circ}, 43^{\circ}$, and $63^{\circ}$ were attributed to the $\mathrm{Ni}$ oxide phase (JCPDS No. 4-835). $\mathrm{NiO}$ and $\mathrm{Ni}_{2} \mathrm{O}_{3}$ were the most common $\mathrm{Ni}$ oxides, and may also exist in the microcrystalline or amorphous phases, while $\mathrm{NiAl}_{2} \mathrm{O}_{4}$ peaks may overlap with the peaks of $\gamma-\mathrm{Al}_{2} \mathrm{O}_{3}{ }^{8}$. The PTA phase $\left(11^{\circ}, 26^{\circ}\right.$, and $34^{\circ}$, JCPDS No. 50-0657) was not observed, as shown in Fig. $5 \mathrm{C}$. 

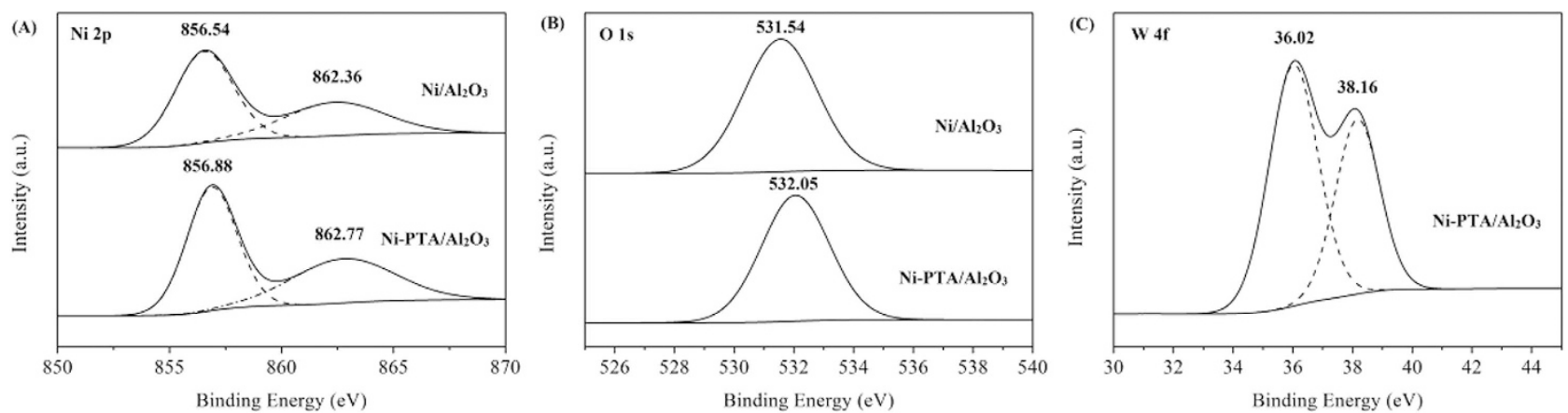

Figure 6. XPS spectra of (a) Ni 2p, (b) O 1 s and (c) W $4 \mathrm{f}$ levels of the synthetic $\mathrm{Ni} / \mathrm{Al}_{2} \mathrm{O}_{3}$ catalyst and the synthetic $\mathrm{Ni}-\mathrm{PTA} / \mathrm{Al}_{2} \mathrm{O}_{3}$ catalyst.

This indicated that the PTA was highly dispersed on the catalyst surface, forming an amorphous surface compound. In addition, there was no diffraction peak in the synthetic Ni-PTA/ $\mathrm{Al}_{2} \mathrm{O}_{3}$ catalyst sample, indicating that the Keggin structure remains intact ${ }^{20}$. However, $\mathrm{Ni}-\mathrm{PTA} / \mathrm{Al}_{2} \mathrm{O}_{3}$ grain and powder catalysts (Fig. 5D,E) exhibited diffraction peaks for PTA. This implied that the crystalline structure of PTA was kept in the mixture, and that the PTA was aggregated due to excessive impregnation onto $\mathrm{Al}_{2} \mathrm{O}_{3}$. This accords with SEM-EDX results (Fig. 3), which showed the differentiated distribution of PTA (Ni and W) on the $\mathrm{Ni}-\mathrm{PTA} / \mathrm{Al}_{2} \mathrm{O}_{3}$ powder.

The XRD patterns of synthetic Ni-PTA/ $/ \mathrm{Al}_{2} \mathrm{O}_{3}$ catalyst with PTA loading (30\%) showed only the diffraction pattern of $\mathrm{NiO}$ and $\mathrm{Al}_{2} \mathrm{O}_{3}$, and no diffraction peak due to PTA was observed. These results suggested that the PTA particles dispersed well on the surface of NiO-doped samples. Compared with the $\mathrm{Ni} / \mathrm{Al}_{2} \mathrm{O}_{3}$ catalyst $(\mathrm{B})$, the peaks of the Ni-PTA/ $/ \mathrm{Al}_{2} \mathrm{O}_{3}$ catalyst $(\mathrm{C})$ were weaker, indicating that the added PTA could increase the dispersion of $\mathrm{Ni}$, leading to the formation of a more active center and increasing catalytic activity.

In addition, TG-DTA analysis (see Supplementary data of Figure S1) confirmed that there was a small loss of weight $(3.97 \%)$ in the TG curve of PTA $\left(\mathrm{H}_{3} \mathrm{PW}_{12} \mathrm{O}_{40} \cdot 6 \mathrm{H}_{2} \mathrm{O}\right)$, and two separated peaks deriving from dehydration of physically adsorbed and crystal water (the loss of $6 \mathrm{H}_{2} \mathrm{O}$ molecules) were observed at temperatures below $125^{\circ} \mathrm{C}$ and around $150-325^{\circ} \mathrm{C}$ in DTA curve. From the DTA curves, it was found that PTA showed one obvious endothermic peak at around $225^{\circ} \mathrm{C}$, and another exothermic peak appeared at $610^{\circ} \mathrm{C}$ which is due to the crystallization of tungstate species formed by the decomposition of PTA. These results were consistent with the reported literature ${ }^{21,22}$. From the analysis of TG-DTA, it can be concluded that PTA species in the catalyst remain its Keggin structure after calcination at $400{ }^{\circ} \mathrm{C}$ in the hydroprocessing, and the observed cracking activity was due to PTA.

XPS spectra for the synthetic $\mathrm{Ni} / \mathrm{Al}_{2} \mathrm{O}_{3}$ catalyst and the synthetic Ni-PTA/ $/ \mathrm{Al}_{2} \mathrm{O}_{3}$ catalyst were shown in Fig. 6 . The Ni $2 \mathrm{p}$ binding energies at $856-863 \mathrm{eV}$ were observed in Fig. $6 \mathrm{~A}$ for the two catalysts. As expected, nickel is present in the $\mathrm{Ni}^{2+}$ oxidation state on the surface. The binding energy of $\mathrm{Ni} 2 \mathrm{p}$ in the region near $856.54 \mathrm{eV}$ is attributed to $\mathrm{Ni}^{2+}$ ions, whereas that around $862.36 \mathrm{eV}$ is known as a satellite peak that appears as a result of multielectron excitation ${ }^{23}$. The shift of the peak towards higher binding energy values for Ni-PTA/ $\mathrm{Al}_{2} \mathrm{O}_{3}$ is assigned to the stronger interaction between $\mathrm{Ni}^{2+}$ and the alumina surface ${ }^{24}$.

Figure 6B showed the O 1s XPS spectra for the two catalysts. The O 1s peak position shifts towards higher binding energy values for the Ni-PTA/ $/ \mathrm{Al}_{2} \mathrm{O}_{3}$ catalyst with a stronger acidic character. The shift towards higher binding energy of more than $0.5 \mathrm{eV}$ for the $\mathrm{O} 1 \mathrm{~s}$ orbital passing from Ni/ $\mathrm{Al}_{2} \mathrm{O}_{3}$ to Ni-PTA/ $\mathrm{Al}_{2} \mathrm{O}_{3}$ is associated with a strong electronegative effect of the chemical species bonded to the acidic surface oxygen sites. This attracts the electron clouds of the Ni-PTA $/ \mathrm{Al}_{2} \mathrm{O}_{3}$, and increased the bond polarization with terminal hydrogen atoms ${ }^{25}$. Thus, the $\mathrm{O} 1 \mathrm{~s}$ peak shift towards high binding energy is indicative of a more acidic behavior and the peak of Ni-PTA $/ \mathrm{Al}_{2} \mathrm{O}_{3}$ catalyst is probably corresponding to $\mathrm{W}-\mathrm{O}-\mathrm{H}^{26}$.

As reported by P.A. Jalil et al. ${ }^{27}$, the $\mathrm{W} 4 \mathrm{f}$ region in pure PTA spectrum showed the spin-orbit split doublet $4 \mathrm{f}_{7 / 2}$ and $4 \mathrm{f}_{5 / 2}$ located at 35.8 and $38.0 \mathrm{eV}$, respectively. Similarly, as shown in Fig. 6C, the Ni-PTA/ $\mathrm{Al}_{2} \mathrm{O}_{3}$ catalyst exhibited the spin-orbit splitting signals of $\mathrm{W}_{7 / 2}$ and $\mathrm{W} 4 \mathrm{f}_{5 / 2}$ at binding energy of 36.02 and $38.16 \mathrm{eV}$, respectively. This result clearly showed the existence of assembled PTA on $\mathrm{Ni} / \mathrm{Al}_{2} \mathrm{O}_{3}$ catalyst. The peaks at low energy were attributed to $\mathrm{W}^{\mathrm{x}}\left(\mathrm{W}^{\mathrm{x}+}\right.$ represents nonstoichiometric $\left.\mathrm{WO}_{\mathrm{x}} / \mathrm{W}\right)$ and the peaks at high energy were attributed to $\mathrm{W}^{6+}$, in agreement with our previous report ${ }^{28}$.

In addition, from the XPS spectra of the Ni $2 p$ level and $\mathrm{W} 4 \mathrm{f}$ level in Fig. $6 \mathrm{~A}$ and Fig. $6 \mathrm{C}$, respectively, we can see that $\mathrm{Ni}$ and $\mathrm{W}$ were present in the form of oxides or hydroxides, which acted as spacers. These metal oxide/hydroxides not only protected the amorphous structure of the catalyst, aiding in hydrogenation activity, but also enhanced the dispersion of active sites $^{29}$. Combining the results of SEM-EDX and $\mathrm{XRD}$, it is reasonable to point out that the metal active sites should be highly dispersed, leading to the formation of more active centers then markedly increasing the catalytic activity. 


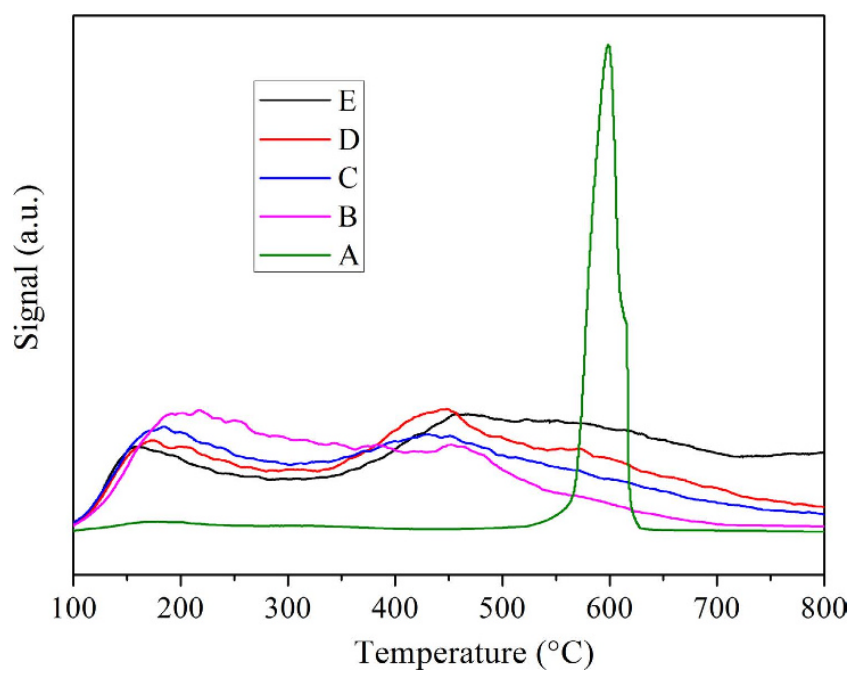

Figure 7. $\mathrm{NH}_{3}$-TPD profiles of (A) pure PTA, (B) synthetic $\mathrm{Al}_{2} \mathrm{O}_{3}$ support, (C) Ni-PTA(10)/ $\mathrm{Al}_{2} \mathrm{O}_{3}$ catalyst, (D) Ni-PTA(30)/ $\mathrm{Al}_{2} \mathrm{O}_{3}$ catalyst and (E) Ni-PTA(50)/ $/ \mathrm{Al}_{2} \mathrm{O}_{3}$ catalyst.

\begin{tabular}{|l|c|c|}
\hline $\begin{array}{l}\text { Surface acidity }(\mathbf{m m o l} / \mathbf{g} \\
\left.\mathbf{N H}_{\mathbf{3}}\right)\end{array}$ & $\begin{array}{c}\text { Weak acidity } \\
\left(\mathbf{1 0 0}-\mathbf{3 0 0}^{\circ} \mathbf{C}\right)\end{array}$ & $\begin{array}{c}\text { Strong acidity } \\
\left(\mathbf{3 0 0 - 8 0 0}{ }^{\circ} \mathbf{C}\right)\end{array}$ \\
\hline Pure PTA & 0.02 & 1.71 \\
\hline Synthetic $\mathrm{Al}_{2} \mathrm{O}_{3}$ & 1.19 & 0.29 \\
\hline Ni-PTA(10) & 0.65 & 0.67 \\
\hline Ni-PTA(30) & 0.53 & 1.22 \\
\hline Ni-PTA(50) & 0.51 & 1.06 \\
\hline
\end{tabular}

Table 2. Acidity of PTA, synthetic support and catalysts from $\mathrm{NH}_{3}-\mathrm{TPD}$.

$\mathrm{NH}_{3}$-TPD was carried out to evaluate the acidic properties of the samples. $\mathrm{NH}_{3}$-TPD profiles of pure PTA, synthetic $\mathrm{Al}_{2} \mathrm{O}_{3}$ support and catalysts with different PTA loadings were shown in Fig. 7. The adsorbed $\mathrm{NH}_{3}$ molecules desorbed from weak acid sites at low temperatures, and from strong acid sites at high temperatures. The TPD profile of pure PTA (Fig. 7A) presented only one desorption peak (maximum $600^{\circ} \mathrm{C}$ ) in the temperature range of $100-800^{\circ} \mathrm{C}$, while synthetic $\mathrm{Al}_{2} \mathrm{O}_{3}$ support (Fig. $7 \mathrm{~B}$ ) showed a broad distribution of the desorption peak in the temperature range of $100-800^{\circ} \mathrm{C}$, with a peak maxima at $217^{\circ} \mathrm{C}$. From the $\mathrm{NH}_{3}$-TPD profiles of $\mathrm{Ni}-\mathrm{PTA}(10-50) / \mathrm{Al}_{2} \mathrm{O}_{3}$ catalyst (Fig. $7 \mathrm{C}-\mathrm{E}$ ), it was found that all catalysts showed similar acid site distribution, but differences in concentration. The Ni-PTA(10-50)/ $\mathrm{Al}_{2} \mathrm{O}_{3}$ catalyst showed two desorption peaks in the temperature range of $100-300^{\circ} \mathrm{C}$ and $300-800^{\circ} \mathrm{C}$, and had two types of acid sites (weak acid sites and strong acid sites) on the surfaces. However, pure PTA did not show an obvious peak in the temperature range of $100-300^{\circ} \mathrm{C}$, while synthetic $\mathrm{Al}_{2} \mathrm{O}_{3}$ support (Fig. 7B) did not show an obvious peak in the temperature range of $300-800^{\circ} \mathrm{C}$, indicating that PTA only had strong acid sites and $\mathrm{Al}_{2} \mathrm{O}_{3}$ did not have strong acid sites on the surface. It was evident from Fig. 7C-E that weak acid sites of all catalyst surfaces decreased with the addition of PTA from 10-50\%, while a monotonic increase in the numbers of strong acid sites as the PTA loading rose. The nature of a solid acid catalyst was mainly determined by the strongest acid sites on the surface ${ }^{30}$. Compared with desorption peak of pure PTA (Fig. 7A), that assigned to the strong acid sites were shifted to lower temperature (about $450^{\circ} \mathrm{C}$ ), showing that the strength of acid sites were further receded, which strongly weaken the coke deposition and restrain the deactivation of the catalyst.

All tested samples showed similar acid site distribution but differences in concentration. Desorption temperatures and the amount of ammonia desorbed on each of the TPD peaks were shown in Table 2. Pure PTA, synthetic support and catalysts all had considerable acidity. The relative ratio of weak acidities decreased in the order: Synthetic $\mathrm{Al}_{2} \mathrm{O}_{3}>\mathrm{Ni}-\mathrm{PTA}(10)>\mathrm{Ni}-\mathrm{PTA}(30) \approx \mathrm{Ni}-\mathrm{PTA}(50)>>$ PTA. From these data, it is evident that strong acidity of $\mathrm{Al}_{2} \mathrm{O}_{3}$ surface increased with the PTA loading up to $30 \mathrm{wt} \%$, and then decreased. It is suggested that the much higher loading leads to the PTA units not spreading well on the $\mathrm{Al}_{2} \mathrm{O}_{3}$ surface and their serious agglomeration, thus lowering the number of accessible strong acid sites ${ }^{31}$.

The coke content in used catalysts was quantitatively analyzed by TGA measurements, and the curves were shown in Fig. 8. According to the reference of ISO 6964-1986, the decoking of carbon deposited on 


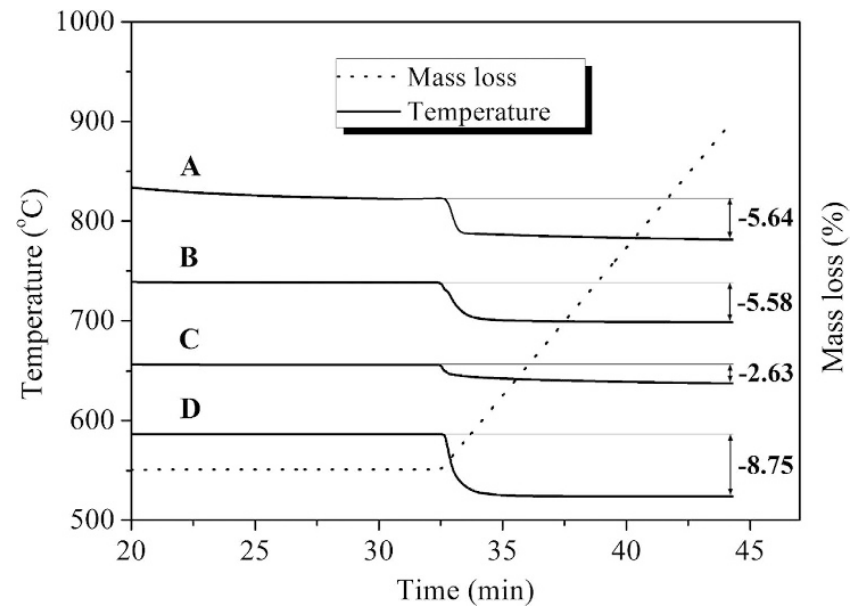

Figure 8. TGA profiles of (A) Ni-PTA/ $\mathrm{Al}_{2} \mathrm{O}_{3}$ grain after use for $10 \mathrm{~h},(\mathbf{B}) \mathrm{Ni}-\mathrm{PTA} / \mathrm{Al}_{2} \mathrm{O}_{3}$ powder after use for $10 \mathrm{~h},(\mathbf{C})$ synthetic $\mathrm{Ni}-\mathrm{PTA} / \mathrm{Al}_{2} \mathrm{O}_{3}$ catalyst after use for $10 \mathrm{~h}$ and (D) $70 \mathrm{~h}$. Reaction conditions: $360^{\circ} \mathrm{C}$, 3.0 MPa, $0.8 \mathrm{~h}^{-1}$.

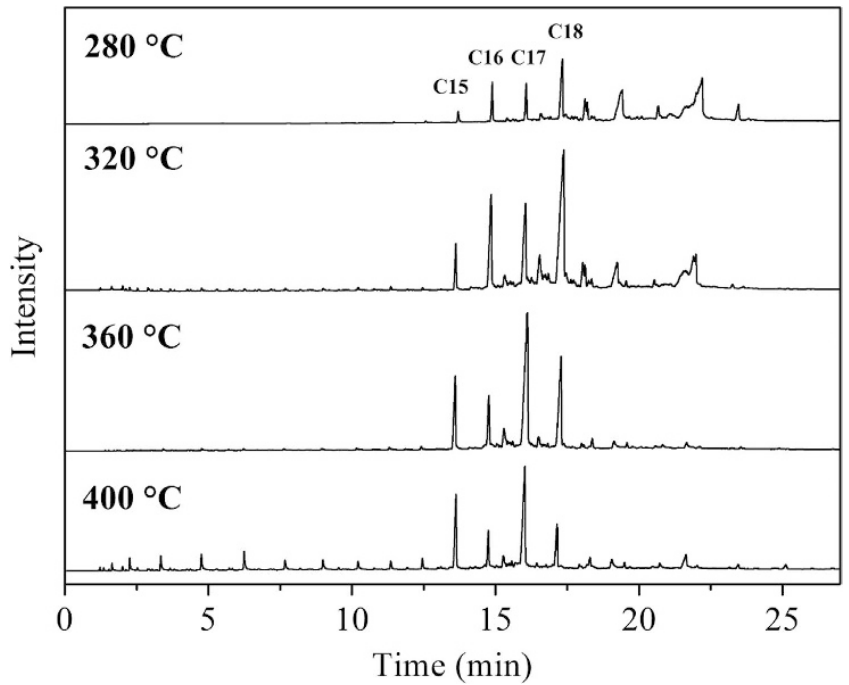

Figure 9. GC charts of product oil from hydroprocessing of Jatropha oil over synthetic Ni-PTA(10)/ $\mathrm{Al}_{2} \mathrm{O}_{3}$ catalyst at $280-400{ }^{\circ} \mathrm{C}, 3.0 \mathrm{MPa}, 0.8 \mathrm{~h}^{-1}$.

the catalyst surface usually occurred at over $550^{\circ} \mathrm{C}$ in an oxidative environment ${ }^{32}$. As shown in Fig. 8, the amounts of carbon deposited on the Ni-PTA/ $\mathrm{Al}_{2} \mathrm{O}_{3}$ grain $(\mathrm{A}=5.64 \%)$ and $\mathrm{Ni}-\mathrm{PTA} / \mathrm{Al}_{2} \mathrm{O}_{3}$ powder $(\mathrm{B}=5.58 \%)$ were both higher than that on synthetic Ni-PTA/ $\mathrm{Al}_{2} \mathrm{O}_{3}$ catalyst $(\mathrm{C}=2.63 \%)$. Compared the reaction of $10 \mathrm{~h}$, the carbon residue of $\mathrm{NiMoLa} / \mathrm{Al}_{2} \mathrm{O}_{3}$ catalyst $(\mathrm{D}=8.75 \%)$ after the reaction of $70 \mathrm{~h}$ increased $6.12 \%$. These results confirmed that the total amount of coke produced varied with different types of support, and the amount of coke on synthetic $\mathrm{Ni}-\mathrm{PTA} / \mathrm{Al}_{2} \mathrm{O}_{3}$ catalyst after use for $10 \mathrm{~h}$ was lowest. Since the reactivity of coke depends on the structure of the catalysts, which was closely related to the morphology of the catalyst ${ }^{33}$, the synthetic catalyst showed a different textural property and morphology than other commercial catalysts studied. This result is in accordance with the BET results, which showed that the surface area and pore diameter of synthetic $\mathrm{Al}_{2} \mathrm{O}_{3}$ support was higher than that of the commercial samples.

Effect of reaction temperature on the composition of product oil. Hydroprocessing temperature is a key parameter for catalyst performance. Figure 9 showed GC charts of liquid product oil from hydroprocessing of Jatropha oil over a synthetic Ni-PTA(10) $/ \mathrm{Al}_{2} \mathrm{O}_{3}$ catalyst on $280-400^{\circ} \mathrm{C}$. As shown in Fig. 9, although $\mathrm{C} 15 \mathrm{H} 32, \mathrm{C} 16 \mathrm{H} 34, \mathrm{C} 17 \mathrm{H} 36$ and $\mathrm{C} 18 \mathrm{H} 38$ were the main products at different temperatures, the amount of smaller molecule alkane $(<\mathrm{C} 15)$ that was formed increased remarkably when the reaction temperature reached $400^{\circ} \mathrm{C}$. When the reaction was carried out at a low reaction temperature of 280 and $320^{\circ} \mathrm{C}$, the peaks of intermediates (such as fatty acids or fatty esters) ${ }^{34}$ were observed in the 


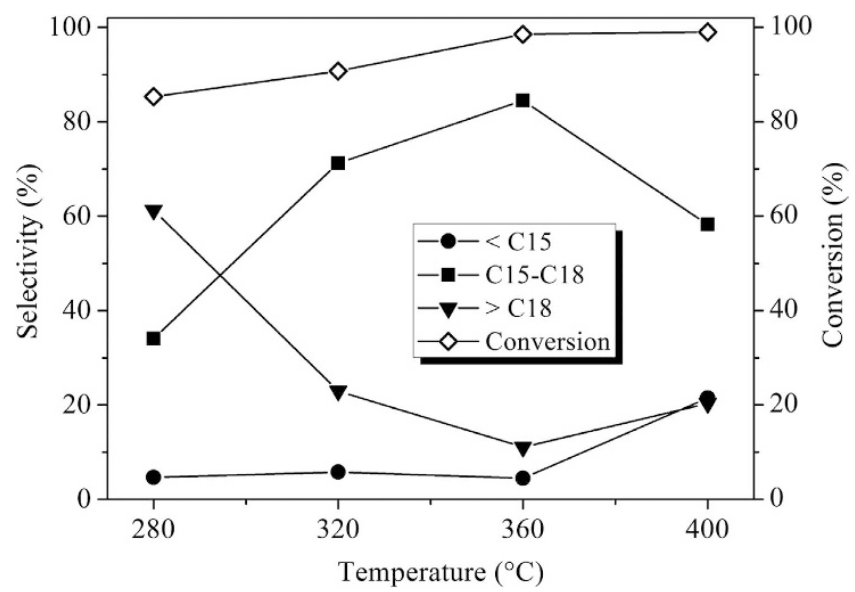

Figure 10. Effect of reaction temperature on selectivity of product oil and conversion of Jatropha oil using a synthetic $\mathrm{Ni}-\mathrm{PTA}(10) / \mathrm{Al}_{2} \mathrm{O}_{3}$ catalyst.

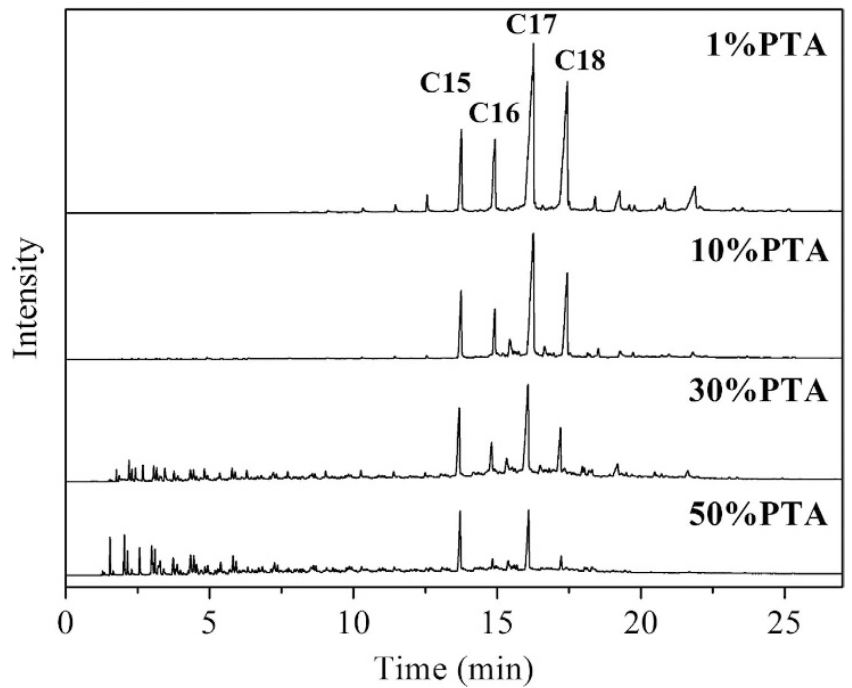

Figure 11. GC charts of product oil from hydroprocessing of Jatropha oil over synthetic Ni-PTA(1-50)/ $\mathrm{Al}_{2} \mathrm{O}_{3}$ catalysts at $360^{\circ} \mathrm{C}, 3.0 \mathrm{MPa}, 0.8 \mathrm{~h}^{-1}$.

GC chart. At temperatures higher than about $360^{\circ} \mathrm{C}$, intermediates were not detected in the product oil. On the other hand, reaction temperature had a relatively strong influence on the ratio of n-alkanes with an even and odd carbon atom number ${ }^{35}$. It was apparent that as the reaction temperature increased, the content of $\mathrm{n}-\mathrm{C} 17$ increased at the expense of $\mathrm{n}-\mathrm{C} 18$.

Jatropha oil was hydroprocessed at a reaction temperatures ranging from 280 to $400^{\circ} \mathrm{C}$ at $3.0 \mathrm{MPa}$, $0.8 \mathrm{~h}^{-1}$. Results for selectivity of product oil and conversion of Jatropha oil were presented in Fig. 10. Conversion increased with increasing reaction temperature, and the lowest conversion exceeded $85 \%$ at the lowest temperature $\left(280^{\circ} \mathrm{C}\right)$. The $\mathrm{C} 15-\mathrm{C} 18$ selectivity increased from 34.1 to $84.5 \%$ as the reaction temperature increased from 280 to $360^{\circ} \mathrm{C}$. This increase is due to an increase in the conversion of triglycerides, free fatty acids and oxygenated intermediates to alkanes ${ }^{36}$. This is evident in the decreasing selectivity trend of the $>\mathrm{C} 18$ fraction, as shown in Fig. 10. The maximum selectivity of the C15-C18 fraction $(84.5 \mathrm{wt} \%)$ was observed at $360^{\circ} \mathrm{C}$. When the temperature increased to $400^{\circ} \mathrm{C}$, the $\mathrm{C} 15-\mathrm{C} 18$ selectivity significantly decreased and the amount of light hydrocarbons $(<\mathrm{C} 15)$ greatly increased. This indicated that temperature played an important role in the cracking of the intermediate carbenium ions ${ }^{4}$ at over $360^{\circ} \mathrm{C}$.

Effect of PTA loading on the composition of product oil. As shown in Fig. 11, the Ni-PTA/Al $\mathrm{O}_{3}$ catalyst formed $\mathrm{n}-\mathrm{C} 15 \mathrm{H} 32, \mathrm{n}-\mathrm{C} 16 \mathrm{H} 34, \mathrm{n}-\mathrm{C} 17 \mathrm{H} 36$, and $\mathrm{n}-\mathrm{C} 18 \mathrm{H} 38$ as the main products. The concentration of smaller molecule alkane $(<\mathrm{C} 15)$ and iso-paraffins (iso/n ratio $=0.06$, see Table 3 ) were very low. In order to improve cold flow properties, PTA-content was increased for the isomerization/cracking of $\mathrm{C} 15 \mathrm{H} 32$ to $\mathrm{C} 18 \mathrm{H} 38$ n-paraffins. Fig. 11 showed the light hydrocarbons $(<\mathrm{C} 15)$, and iso-paraffins 


\begin{tabular}{|l|c|c|c|c|}
\hline Catalyst & Ni-PTA(1) & Ni-PTA(10) & Ni-PTA(30) & Ni-PTA(50) \\
\hline Conversion (\%) & 93.32 & $\mathbf{9 8 . 5 2}$ & 96.68 & 95.70 \\
\hline C15-C18 selectivity (\%) & 78.01 & $\mathbf{8 4 . 4 7}$ & 56.31 & 30.75 \\
\hline$(\mathrm{C} 15+$ C17)/(C16+C18) ratio & 1.25 & $\mathbf{1 . 8 1}$ & 2.06 & 4.92 \\
\hline Iso/n ratio & 0.06 & $\mathbf{0 . 2 4}$ & 1.03 & 1.15 \\
\hline Pour point $\left({ }^{\circ} \mathrm{C}\right)$ & 20 & $\mathbf{- 1 0}$ & -18 & - $^{\mathrm{a}}$ \\
\hline
\end{tabular}

Table 3. Hydroprocessing of Jatropha oil on Ni-PTA(1-50)/ $\mathrm{Al}_{2} \mathrm{O}_{3}$ catalysts at $360{ }^{\circ} \mathrm{C}, 3.0 \mathrm{MPa}, 0.8 \mathrm{~h}^{-1}$. ${ }^{\text {a Lower than }}-20^{\circ} \mathrm{C}$.

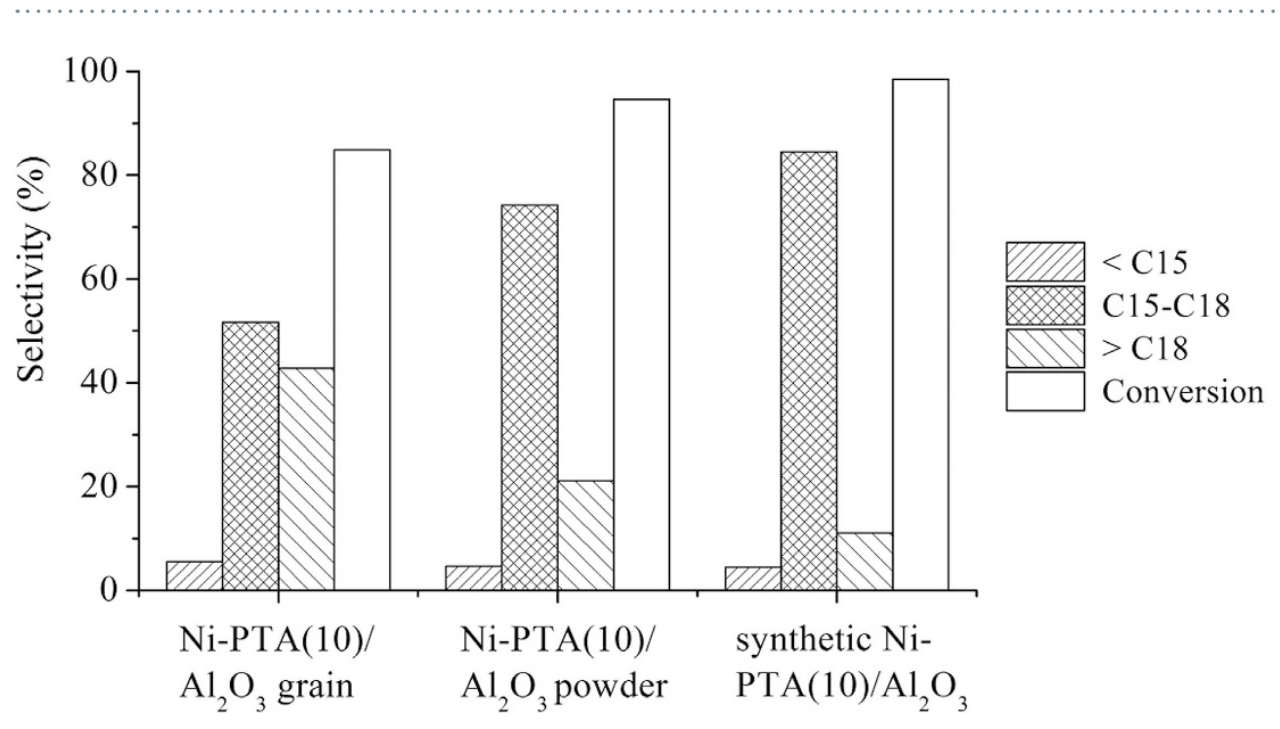

Figure 12. Effect of alumina supports on the selectivity of product oil and conversion of Jatropha oil at $360^{\circ} \mathrm{C}, 3.0 \mathrm{MPa}, 0.8 \mathrm{~h}^{-1}$.

increased with increasing PTA-content. Ni-PTA(50)/ $\mathrm{Al}_{2} \mathrm{O}_{3}$ catalysts formed many light hydrocarbons $(<\mathrm{C} 15)$ and iso-paraffins (iso/n ratio $=1.15$, see Table 3$)$. This result accorded with results of $\mathrm{NH}_{3}-\mathrm{TPD}$ (see Fig. 7), which showed that the strong acid sites of all catalysts increase with the addition of PTA from 10-50\%. According to the proposed bifunctional mechanism ${ }^{4}$, after $\mathrm{C} 17 \mathrm{H} 36$ and $\mathrm{C} 18 \mathrm{H} 38$ formed by the hydroprocessing of Jatropha oil on $\mathrm{Ni} / \mathrm{W}$ sites, the corresponding carbenium intermediates were formed on the acid sites of PTA. The carbenium intermediates underwent cracking to form light hydrocarbons as well as isomerization to form isoparaffins.

The isomerization/cracking of n-paraffins over bifunctional catalysts containing metal and solid acid is very important for improving the properties of liquid hydrocarbon fuels ${ }^{30}$. In Table 3, there was an obvious increase of i-alkane content with increasing PTA-content for all tested catalysts. The liquid hydrocarbons formed over Ni-PTA(10) contained many C15-C18 fractions (78.0 wt\%), but the pour point of the product was too high $\left(20^{\circ} \mathrm{C}\right)$ to use as a diesel fuel. Although the pour point of liquid hydrocarbons formed over Ni-PTA(30) and Ni-PTA(50) were low enough, C15-C18 selectivity was also low. This is because it formed a large amount of $<\mathrm{C} 15$ fraction (see Fig. 10) on the strong acid sites. Thus, $\mathrm{Ni}-\mathrm{PTA}(10)$ produced the largest amount of $\mathrm{C} 15-\mathrm{C} 18$ hydrocarbon product $(84.5 \mathrm{wt} \%)$ with a pour point of $-10^{\circ} \mathrm{C}$, which was suitable for producing green diesel from the Jatropha oil.

Influence of alumina supports on the catalytic activity. Figure 12 showed the conversion of Jatropha oil and product selectivities over Ni-PTA/ $\mathrm{Al}_{2} \mathrm{O}_{3}$ grain, $\mathrm{Ni}-\mathrm{PTA} / \mathrm{Al}_{2} \mathrm{O}_{3}$ powder and synthetic $\mathrm{Ni}-\mathrm{PTA} / \mathrm{Al}_{2} \mathrm{O}_{3}$ catalysts in the hydroprocessing of Jatropha oil. All PTA content in the catalysts was at $10 \%$. The conversion of Jatropha oil was more than $80 \%$ over each catalyst, and increased in the following order: synthetic Ni-PTA $/ \mathrm{Al}_{2} \mathrm{O}_{3}$ catalyst $>\mathrm{Ni}-\mathrm{PTA} / \mathrm{Al}_{2} \mathrm{O}_{3}$ powder $>\mathrm{Ni}-\mathrm{PTA} / \mathrm{Al}_{2} \mathrm{O}_{3}$ grain. The selectivity of light fraction $(<\mathrm{C} 15)$ was in a narrow range of $4.5-5.6 \%$ over each catalyst. The $\mathrm{C} 15-\mathrm{C} 18$ hydrocarbon selectivity was highest (84.5\%) over the synthetic $\mathrm{Ni}-\mathrm{PTA} / \mathrm{Al}_{2} \mathrm{O}_{3}$ catalyst. It was $51.6 \%$ and $74.3 \%$ over the Ni-PTA $/ \mathrm{Al}_{2} \mathrm{O}_{3}$ grain and $\mathrm{Ni}-\mathrm{PTA} / \mathrm{Al}_{2} \mathrm{O}_{3}$ powder catalyst, respectively, due to the considerable heavy fraction ( $>\mathrm{C} 18$ ). The corresponding XRD data (Fig. 5) revealed that large PTA agglomerates formed in the Ni-PTA $/ \mathrm{Al}_{2} \mathrm{O}_{3}$ grain and powder catalysts. These agglomerates cannot enter the pores of the support, and therefore block the pore mouths. Consequently, PTA dispersion and amount of accessible acid sites decreased on the surface of $\mathrm{Ni}-\mathrm{PTA} / \mathrm{Al}_{2} \mathrm{O}_{3}$ grain and powder catalysts, which led to a decline in the 
conversion of Jatropha oil and C15-C18 selectivity ${ }^{37}$. From the results of BET and TGA, synthetic $\mathrm{Al}_{2} \mathrm{O}_{3}$ support had the highest surface area $\left(296 \mathrm{~m}^{2} / \mathrm{g}\right)$, and synthetic Ni-PTA/ $\mathrm{Al}_{2} \mathrm{O}_{3}$ catalysts showed the least amount of coke $(2.63 \%)$. Thus, the results of catalytic activity were consistent with that of BET and TGA. Synthetic Ni-PTA/ $\mathrm{Al}_{2} \mathrm{O}_{3}$ catalysts presented the best catalytic activity among the test samples.

\section{Discussion}

Green diesel (renewable C15-C18 alkanes) can be produced from hydroprocessing of Jatropha oil over $\mathrm{Ni}-\mathrm{PTA} / \mathrm{Al}_{2} \mathrm{O}_{3}$ catalysts. The maximum conversion of Jatropha oil ( $98.5 \mathrm{wt} \%$ ), and selectivity of the $\mathrm{C} 15-\mathrm{C} 18$ fraction $(84.5 \mathrm{wt} \%)$ was observed at $360^{\circ} \mathrm{C}, 3.0 \mathrm{MPa}, 0.8 \mathrm{~h}^{-1}$ using synthetic Ni-PTA/Al $\mathrm{O}_{3}$ catalyst (PTA $10 \mathrm{wt} . \%)$.

Results of BET and $\mathrm{NH}_{3}$-TPD indicated that the pore structure, physicochemical adsorption properties, and acidity of supports and catalysts can affect hydroprocessing catalytic activity. SEM-EDX, TEM and XRD results showed that $\mathrm{Ni}$ and $\mathrm{W}$ species were distributed on the surface of the synthetic Ni-PTA/ $\mathrm{Al}_{2} \mathrm{O}_{3}$ catalyst evenly and no aggregates were observed. This led to the formation of a more active center. XPS clearly showed the existence of assembled PTA on $\mathrm{Ni} / \mathrm{Al}_{2} \mathrm{O}_{3}$ catalyst. $\mathrm{Ni}$ and $\mathrm{W}$ metal oxide/hydroxides not only protected the amorphous structure of the catalyst, aiding in hydrogenation activity, but also enhanced dispersion of active sites.

GC charts showed that $\mathrm{C} 15 \mathrm{H} 32, \mathrm{C} 16 \mathrm{H} 34, \mathrm{C} 17 \mathrm{H} 36$ and $\mathrm{C} 18 \mathrm{H} 38$ were the main products. There was an obvious increase of i-alkane content with increasing PTA-content for all tested catalysts and the amount of smaller molecule alkane increased with increasing reaction temperatures. In this work, the mass balance, through the ratio of the unit time obtained product quantity $(7.9 \mathrm{~g} / \mathrm{h})$ and consumed reactant quantity $(8.1 \mathrm{~g} / \mathrm{h})$, is calculated as $(7.9 / 8.1) \times 100 \%=97.5 \%$. The yields of the main products from hydrotreated Jatropha oil were liquid products at $93.2 \mathrm{wt} \%$ (including water $1.5 \mathrm{wt} \%$ ) and gaseous products at $5.3 \mathrm{wt} \%$ over the Ni-PTA $(10) / \mathrm{Al}_{2} \mathrm{O}_{3}$ catalyst at $360^{\circ} \mathrm{C}, 3.0 \mathrm{MPa}, 0.8 \mathrm{~h}^{-1}$. The gaseous products contained mainly $\mathrm{CO}(2.94 \mathrm{wt} \%), \mathrm{CO}_{2}(0.28 \mathrm{wt} \%)$, propane $(1.57 \mathrm{wt} \%)$ and methane $(0.48 \mathrm{wt} \%)$. The ratio of $\mathrm{CO}$ and $\mathrm{CO}_{2}$ to $\mathrm{H}_{2} \mathrm{O}$ was calculated as 2.14 , in accordance with the ratio of $(\mathrm{C} 15+\mathrm{C} 17) /(\mathrm{C} 16+\mathrm{C} 18)$ in Table 3. From the composition of the gas and liquid products, it can be deduced that the triglyceride is hydrogenated and broken down into various intermediates. Then the intermediates are converted into alkanes by two pathways: Hydrocarbons with the same carbon number as the fatty acids in triglycerides, i.e., $\mathrm{C} 18 \mathrm{H} 38$ and $\mathrm{C} 16 \mathrm{H} 34$, are the products of hydrodeoxygenation (HDO). Hydrocarbons with one carbon atom less than the fatty acids in triglycerides, i.e., $\mathrm{C} 17 \mathrm{H} 36$ and $\mathrm{C} 15 \mathrm{H} 32$, are the products of oxygen removal from triglyceride by hydrodecarboxylation (HDC), including decarboxylation + decarbonylation $^{2}$. Figure 9 showed that with increasing reaction temperature, HDC came into play more prominently. Table 3 showed that the relative ratio of $(\mathrm{C} 15+\mathrm{C} 17) /(\mathrm{C} 16+\mathrm{C} 18)$ increased from 1.25 to 4.92 with increasing PTA-content (1-50\%). Thus, the selectivity to the decarbonylation plus decarboxylation products (as compared to the hydrodeoxygenation pathway) increased with increasing PTA-content.

Compared with the Ni-PTA $/ \mathrm{Al}_{2} \mathrm{O}_{3}$ catalyst using commercial alumina grain and powder as the supports, the synthetic Ni-PTA/ $/ \mathrm{Al}_{2} \mathrm{O}_{3}$ catalyst showed the best catalytic performance. TGA of three catalysts indicated that total amount of coke produced varied with different types of supports. The amount of coke on synthetic Ni-PTA $/ \mathrm{Al}_{2} \mathrm{O}_{3}$ catalyst after use for $10 \mathrm{~h}$ was lowest. Furthermore, applying transition metal and heteropolyacid catalysts in the hydroprocessing of Jatropha oil can eliminate the sulfurization step and prevent harm from sulfide to the environment and human health.

\section{Methods}

Catalyst preparation and characterization. In this study, a synthetic Ni-PTA/ $\mathrm{Al}_{2} \mathrm{O}_{3}$ catalyst was prepared as follows. First, a synthetic $\mathrm{Ni} / \mathrm{Al}_{2} \mathrm{O}_{3}(5 \mathrm{wt} \% \mathrm{Ni})$ catalyst was prepared with the co-precipitation method. A solution of $70.8 \mathrm{~g} \mathrm{AlCl}_{3} \cdot 6 \mathrm{H}_{2} \mathrm{O}$ and $4.6 \mathrm{~g} \mathrm{Ni}\left(\mathrm{NO}_{3}\right)_{2} \cdot 6 \mathrm{H}_{2} \mathrm{O}$ was dissolved in $100 \mathrm{~mL}$ of water. An $\mathrm{NH}_{3} \cdot \mathrm{H}_{2} \mathrm{O}$ solution $(20 \mathrm{wt} \%$ ) was added to the above mixed solution to adjust the $\mathrm{pH}$ to 8 , with vigorous agitation, and the temperature was maintained at $50{ }^{\circ} \mathrm{C}$ for about $2 \mathrm{~h}$. After the reaction was complete, the mixture was aged at $50^{\circ} \mathrm{C}$ for $12 \mathrm{~h}$ in a water bath. Then the light blue precipitate was collected and washed with water three times. Finally, the precipitate was dried overnight at $100^{\circ} \mathrm{C}$ and calcined in a muffle oven at $400^{\circ} \mathrm{C}$ for $4 \mathrm{~h}$. Next, the Ni-PTA(x)/ $\mathrm{Al}_{2} \mathrm{O}_{3}$ catalyst (where $\mathrm{x}$ indicates PTA content from 1 to $50 \mathrm{wt} \%$ ) was prepared by impregnanting $\mathrm{Ni} / \mathrm{Al}_{2} \mathrm{O}_{3}$ catalyst with a solution containing PTA. Impregnated samples were dried at $100^{\circ} \mathrm{C}$ for $3 \mathrm{~h}$ and calcined at $200^{\circ} \mathrm{C}$ for $3 \mathrm{~h}$.

Two commercial alumina supports were selected to compare with the synthetic $\mathrm{Al}_{2} \mathrm{O}_{3}$ support. The $\mathrm{Ni}-\mathrm{PTA} / \mathrm{Al}_{2} \mathrm{O}_{3}$ catalyst was prepared by wet impregnation, and the detailed preparation was described as follows. The catalyst $\mathrm{Ni} / \mathrm{Al}_{2} \mathrm{O}_{3}(5 \mathrm{wt} \% \mathrm{Ni})$ was prepared by impregnating aqueous solutions of $\mathrm{Ni}\left(\mathrm{NO}_{3}\right)_{2}$ on the support $\mathrm{Al}_{2} \mathrm{O}_{3}$ grain (diameter $2-3 \mathrm{~mm}$ ) or $\mathrm{Al}_{2} \mathrm{O}_{3}$ powder (diameter $0.2-0.3 \mathrm{~mm}$ ). Impregnated samples were dried overnight at $105^{\circ} \mathrm{C}$ and calcined at $400^{\circ} \mathrm{C}$ for $4 \mathrm{~h}$. The $\mathrm{Ni}-\mathrm{PTA} / \mathrm{Al}_{2} \mathrm{O}_{3}$ catalyst was prepared by impregnating the $\mathrm{Ni} / \mathrm{Al}_{2} \mathrm{O}_{3}$ catalyst with a solution containing 1 to $50 \mathrm{wt} \% \mathrm{PTA}$. Impregnated samples were dried at $100^{\circ} \mathrm{C}$ for $3 \mathrm{~h}$ and calcined at $200^{\circ} \mathrm{C}$ for $3 \mathrm{~h}$.

The BET specific surface area, average pore diameter and pore volume of catalysts were determined by $\mathrm{N}_{2}$ isothermal adsorption using the V-Sorb 2800 TP Surface Area and Pore Distribution Analyzer instrument. Scanning electron microscopy (SEM) was conducted with a JSM-6700 (JEOL SEM Co., Japan) instrument to investigate surface morphology and particle size. Elemental mapping images of samples were taken with a CamScan Apollo300 scanning electron microscope (SEM) equipped with 
X-ray energy-dispersive (EDX) microanalyzer (OXFORD INCA). Transmission electron microscopy (TEM) images were collected from a JEOL JEM-2100F field emission electron microscope operated at $200 \mathrm{kV}$. The ex situ treated samples were supported on $\mathrm{Cu}$ grids for the observations. X-ray diffraction (XRD) was used to determine the structural properties of the catalysts. These measurements were performed with a Rigaku D/max-RA XRD analyzer $(\mathrm{Cu}-\mathrm{K} \alpha)$ and PIXcel ${ }^{3 \mathrm{D}}$ detector from the PANalytical Company. Samples were measured in the $2 \theta$ range from $10^{\circ}$ to $80^{\circ}$ (scan speed of $0.02^{\circ}$ per second). X-ray photoelectron spectroscopy (XPS) data were obtained using an ESCALab250 electron spectrometer from Thermo Scientific Corporation with nonmonochromatic $300 \mathrm{~W}$ AlK $\alpha$ radiation. Pass energy for the narrow scan was $30 \mathrm{eV}$. Base pressure was at about $6.5 \times 10^{-10} \mathrm{mbar}$. Binding energies were referenced to the $\mathrm{C} 1 \mathrm{~s}$ line at $284.8 \mathrm{eV}$ from alkyl or adventious carbon. The acidity of catalysts were measured with a temperature programmed desorption of ammonia ( $\left.\mathrm{NH}_{3}-\mathrm{TPD}\right)$ using a chemisorption analyzer, TP-5080 (Tianjin Xianquan Industrial Trade and Development CO., Ltd) with a thermal conductivity detector. All samples were saturated with $\mathrm{NH}_{3}$ at $100^{\circ} \mathrm{C}$, and then flushed with $\mathrm{N}_{2}$ to remove the physically adsorbed $\mathrm{NH}_{3}$. Finally, desorption of $\mathrm{NH}_{3}$ was carried out from 100 to $700^{\circ} \mathrm{C}$ at a heating rate of $10^{\circ} \mathrm{C} / \mathrm{min}$. Thermo gravimetric analysis (TGA) was performed with a SDT-Q600 analyzer to determine the amount of carbon deposited on the used catalysts. Samples were first heated from 30 to $550^{\circ} \mathrm{C}$ at a heating rate of $30^{\circ} \mathrm{C} / \mathrm{min}$ in $\mathrm{N}_{2}$ using a flow of $100 \mathrm{ml} / \mathrm{min}$, at a constant temperature of $550^{\circ} \mathrm{C}$ for $15 \mathrm{~min}$. They were then heated linearly at $30^{\circ} \mathrm{C} / \mathrm{min}$ to $900^{\circ} \mathrm{C}$ in $100 \mathrm{ml} / \mathrm{min} \mathrm{O}_{2}$. The weight loss of samples was processed by microcomputer.

Catalytic activity measurements. Jatropha oil was purchased from Jiangsu Donghu Bioenergy Co., Ltd. and chemical components were confirmed by GC-MS. The distribution of fatty acids was as follows: palmitoleic acid $0.57 \%$, palmitic acid $12.03 \%$, linoleic acid $33.69 \%$, oleic acid $45.41 \%$, stearic acid $8.14 \%$, eicosenoic acid $0.16 \%$.

Experiments were performed in a fixed-bed reactor equipped with an electrically heating system. A detailed description of the apparatus is provided elsewhere ${ }^{38}$. The non-sulfided catalyst $(10 \mathrm{~g})$ was loaded into a stainless steel tubular reactor $(1.2 \mathrm{~cm} \mathrm{I.D} \mathrm{and} 56 \mathrm{~cm}$ in length) and activated in situ prior to the experiments with $\mathrm{H}_{2}$ at $400^{\circ} \mathrm{C}$ and $3.5 \mathrm{MPa}$ for $3 \mathrm{~h}$. The reaction conditions for the catalytic hydroprocessing experiment were as follows: temperature $280-400^{\circ} \mathrm{C}$, pressure $3.0 \mathrm{MPa}$, LHSV $0.8 \mathrm{~h}^{-1}$, and $\mathrm{H}_{2}$ to feed ratio of $1000 \mathrm{~mL} \mathrm{H}_{2}$ gas/mL liquid feed.

The liquid products were withdrawn after stabilization of reaction conditions $(6 \mathrm{~h})$ in one-hour intervals and analyzed with off-line gas chromatography (GC) after separation of the water phase. Gaseous products and water were not further analyzed. Liquid products were analyzed using a GC-900C equipped with AT. SE-30 column $(\mathrm{L}=30 \mathrm{~m}, \mathrm{~d}=0.32 \mathrm{~mm}, \mathrm{tf}=0.5 \mu \mathrm{m})$ and detected by a flame ionization detector (FID). Helium was used as the carrier gas. The following temperature program was used: initial temperature at $60^{\circ} \mathrm{C}$ for $2 \mathrm{~min}$, heating at $15^{\circ} \mathrm{C} / \mathrm{min}$ to $210^{\circ} \mathrm{C}$, then at $8{ }^{\circ} \mathrm{C} / \mathrm{min}$ to $270^{\circ} \mathrm{C}$, and at $5^{\circ} \mathrm{C} / \mathrm{min}$ to $285^{\circ} \mathrm{C}$, with a dwelling time of $5 \mathrm{~min}$ at $285^{\circ} \mathrm{C}$. Individual products were identified by GC standards. The conversion of Jatropha oil was calculated as:

$$
\mathrm{C}=100 \%-\mathrm{C}_{(\mathrm{T})}
$$

where $\mathrm{C}_{(\mathrm{T})}$ is the concentrations of triglycerides (\%) in the product oil, determined by GC analysis. The selectivity of C15-C18 alkanes was calculated as:

$$
\mathrm{S}=\mathrm{Y} / \mathrm{C} \times 100 \%
$$

where $\mathrm{Y}$ is the yield of the $\mathrm{C} 15-\mathrm{C} 18$ alkane (\%), determined by GC analysis, and $\mathrm{C}$ is the conversion of Jatropha oil (\%), calculated by Eq. (1).

\section{References}

1. Li, H., Shen, B., Kabalu, J. C. \& Nchare, M. Enhancing the production of biofuels from cottonseed oil by fixed-fluidized bed catalytic cracking. Renew. Energy. 34, 1033-1039 (2009).

2. Kumar, R. et al. Hydroprocessing of jatropha oil and its mixtures with gas oil. Green Chem. 12, 2232-2239 (2010).

3. Suresh, C. et al. Mo-Ni/Al-SBA-15 (Sulfide) Catalysts for Hydrodenitrogenation: Effect of Si/Al Ratio on Catalytic Activity. ACS Catalysis. 2, 127-134 (2011).

4. Sánchez M., J. F., Boldrini, D. E., Tonetto, G. M. \& Damiani, D. E. Palladium catalyst on anodized aluminum monoliths for the partial hydrogenation of vegetable oil. Chem. Eng. J. 167, 355-361 (2011).

5. Wang, W. et al. Ultrasound-assisted preparation of titania-alumina support with high surface area and large pore diameter by modified precipitation method. J. Alloys Compd. 509, 3430-3434 (2011).

6. Zhang, Q. et al. Aqueous phase reforming of sorbitol to bio-gasoline over Ni/HZSM-5 catalysts. Appl. Energy. 97, 509-513 (2012).

7. Yin, M. et al. Effect of alumina support on catalytic performance of $\mathrm{Pt}-\mathrm{Sn} / \mathrm{Al} 2 \mathrm{O} 3$ catalysts in one-step synthesis of N-phenylbenzylamine from aniline and benzyl alcohol. Chin. J. Catal. 34, 1534-1542 (2013).

8. Kiatkittipong, W. et al. Diesel-like hydrocarbon production from hydroprocessing of relevant refining palm oil. Fuel Process. Technol. 116, 16-26 (2013).

9. Veriansyah, B. et al. Production of renewable diesel by hydroprocessing of soybean oil: Effect of catalysts. Fuel. 94, 578-585 (2012).

10. Kim, S. K., Brand, S., Lee, H. S., Kim, Y. \& Kim, J. Production of renewable diesel by hydrotreatment of soybean oil: Effect of reaction parameters. Chem. Eng. J. 228, 114-123 (2013). 
11. Yakovlev, V. A. et al. Development of new catalytic systems for upgraded bio-fuels production from bio-crude-oil and biodiesel. Catal. Today. 144, 362-366 (2009).

12. Liu, J., Fan, K., Tian, W., Liu, C. \& Rong, L. Hydroprocessing of Jatropha oil over NiMoCe/Al2O3 catalyst. Int. J. Hydrogen Energy. 37, 17731-17737 (2012).

13. Liu, C., Liu, J., Zhou, G., Tian, W. \& Rong, L. A cleaner process for hydrocracking of jatropha oil into green diesel. J. Taiwan Inst. Chem. Eng. 44, 221-227 (2013).

14. Liu, C., Liu, J., Zhou, G., Tian, W. \& Rong, L. Transformation of Jatropha oil into green diesel over a new heteropolyacid catalyst. Environ. Prog. Sustain. Energy. 32, 1240-1246 (2013).

15. Das, S. K. \& El-Safty, S. A. Development of Mesoscopically Assembled Sulfated Zirconia Nanoparticles as Promising Heterogeneous and Recyclable Biodiesel Catalysts. Chem CatChem. 5, 3050-3059 (2013).

16. Wang, S., Li, X., Yin, Q., Zhu, L. \& Luo, Z. Highly active and selective $\mathrm{Cu} / \mathrm{SiO} 2$ catalysts prepared by the urea hydrolysis method in dimethyl oxalate hydrogenation. Catal. Commun. 12, 1246-1250 (2011).

17. Yin, A., Guo, X., Dai, W. L. \& Fan, K. Effect of initial precipitation temperature on the structural evolution and catalytic behavior of $\mathrm{Cu} / \mathrm{SiO} 2$ catalyst in the hydrogenation of dimethyloxalate. Catal. Commun. 12, 412-416 (2011).

18. He, S., Sun, C., Bai, Z., Dai, X. \& Wang, B. Dehydrogenation of long chain paraffins over supported Pt-Sn-K/Al2O3 catalysts: A study of the alumina support effect. Appl. Catal. A-Gen. 356, 88-98 (2009).

19. Badday, A. S., Abdullah, A. Z. \& Lee, K. T. Ultrasound-assisted transesterification of crude Jatropha oil using alumina-supported heteropolyacid catalyst. Appl. Energy. 105, 380-388 (2013).

20. Kumar, A. et al. Nitration of phenol over silica supported H4PW11VO40 catalyst. Catal. Commun. 18, 37-40 (2012).

21. Parida, K. M. \& Mallick, S. Phosphotungstic acid promoted zirconia-alumina mixed oxides: A stable and reusable catalysts for epoxidation of trans-stilbene. Catal. Commun. 11, 51-57 (2009).

22. Tang, L., Luo, G., Zhu, M., Kang, L. \& Dai, B. Preparation, characterization and catalytic performance of HPW-TUD-1 catalyst on oxidative desulfurization. J. Ind. Eng. Chem. 19, 620-626 (2013).

23. Echeandia, S., Arias, P. L., Barrio, V. L., Pawelec, B. \& Fierro, J. L. G. Synergy effect in the HDO of phenol over Ni-W catalysts supported on active carbon: Effect of tungsten precursors. Appl. Catal. B-Environ. 101, 1-12 (2010).

24. Nikolova, D. et al. Surface properties of the Ni-silica gel catalyst precursors for the vegetable oil hydrogenation process: N2 sorption and XPS studies. Russ. J. Phys. Chem. 85, 2380-2385 (2011).

25. Aricò, A. S. et al. Surface properties of inorganic fillers for application in composite membranes-direct methanol fuel cells. J. Power Sources. 128, 113-118 (2004).

26. Jalil, P. A., Faiz, M., Tabet, N., Hamdan, N. M. \& Hussain, Z. A study of the stability of tungstophosphoric acid, H3PW12O40, using synchrotron XPS, XANES, hexane cracking, XRD, and IR spectroscopy. J. Catal. 217, 292-297 (2003).

27. Jalil, P. A., Tabet, N., Faiz, M., Hamdan, N. M. \& Hussain, Z. Surface investigation on thermal stability of tungstophosphoric acid supported on MCM-41 using synchrotron radiation. Appl. Catal. A-Gen. 257, 1-6 (2004)

28. Fan, K., Liu, J., Yang, X. \& Rong, L. Hydrocracking of Jatropha oil over Ni-H3PW12O40/nano-hydroxyapatite catalyst. Int. J. Hydrogen Energ. 39, 3690-3697 (2014).

29. Chen, L. F. \& Chen, Y. W. Effect of Additive (W, Mo, and Ru) on Ni-B Amorphous Alloy Catalyst in Hydrogenation of p-Chloronitrobenzene. Ind. Eng. Chem. Res. 45, 8866-8873 (2006).

30. Liu, Y., Sotelo-Boyás, R., Murata, K., Minowa, T. \& Sakanishi, K. Production of Bio-Hydrogenated Diesel by Hydrotreatment of High-Acid-Value Waste Cooking Oil over Ruthenium Catalyst Supported on Al-Polyoxocation-Pillared Montmorillonite. Catal. 2, 171-190 (2012).

31. Zhao, Z., Dai, Y., Bao, T., Li, R. \& Wang, G. Direct alkenylation of aromatics with phenylacetylene over supported H3PW12O40 catalysts as a clean and highly efficient approach to producing $\alpha$-arylstyrenes. J. Catal. 288, 44-53 (2012).

32. Zhu, J. et al. The promoting effect of $\mathrm{La}, \mathrm{Mg}, \mathrm{Co}$ and $\mathrm{Zn}$ on the activity and stability of $\mathrm{Ni} / \mathrm{SiO} 2$ catalyst for $\mathrm{CO} 2$ reforming of methane. Int. J. Hydrogen Energy. 36, 7094-7104 (2011).

33. Echeandia, S., Arias, P., Barrio, V., Pawelec, B. \& Fierro, J. Synergy effect in the HDO of phenol over Ni-W catalysts supported on active carbon: Effect of tungsten precursors. Appl. Catal. B-Environ. 101, 1-12 (2010).

34. Simacek, P. et al. Premium quality renewable diesel fuel by hydroprocessing of sunflower oil. Fuel. 90, 2473-2479 (2011).

35. Šimáček, P., Kubička, D., Šebor, G. \& Pospíšil, M. Hydroprocessed rapeseed oil as a source of hydrocarbon-based biodiesel. Fuel. 88, 456-460 (2009).

36. Huber, G. W., O'Connor, P. \& Corma, A. Processing biomass in conventional oil refineries: Production of high quality diesel by hydrotreating vegetable oils in heavy vacuum oil mixtures. Appl. Catal. A-Gen. 329, 120-129 (2007).

37. Ning, L. et al. Glycerol Dehydration to Acrolein over Activated Carbon-Supported Silicotungstic Acids. Chin. J. Catal. 29, 212214 (2008).

38. Liu, J., Liu, C., Zhou, G., Shen, S. \& Rong, L. Hydrotreatment of Jatropha oil over NiMoLa/Al2O3 catalyst. Green Chem. 14, 2499-2505 (2012).

\section{Acknowledgements}

This work was supported by the "Fundamental Research Funds for the Central Universities" (NO. BLX2013006) and "Beijing Natural Science Foundation" (2142024).

\section{Author Contributions}

J.D.L. initiated the project and conceived. R.L. supervised the experiments. J.L. analyzed the data and wrote the paper. J.H. and L.H.D. prepared and characterized the samples. K.F. and L.Y.W. provided assistance with the analysis of the data and the revision of the paper, respectively. All authors reviewed the manuscript.

\section{Additional Information}

Supplementary information accompanies this paper at http://www.nature.com/srep

Competing financial interests: The authors declare no competing financial interests.

How to cite this article: Liu, J. et al. Hydroprocessing of Jatropha Oil for Production of Green Diesel over Non-sulfided Ni-PTA/Al $\mathrm{O}_{3}$ Catalyst. Sci. Rep. 5, 11327; doi: 10.1038/srep11327 (2015). 
(c) (i) This work is licensed under a Creative Commons Attribution 4.0 International License. The images or other third party material in this article are included in the article's Creative Commons license, unless indicated otherwise in the credit line; if the material is not included under the Creative Commons license, users will need to obtain permission from the license holder to reproduce the material. To view a copy of this license, visit http://creativecommons.org/licenses/by/4.0/ 